\title{
Tannins reduce protein but not phosphorus utilization of diet with added phytase in pigs*
}

\author{
J. Salobir'1, B. Kostanjevec, M. Štruklec and K. Salobir \\ Institute of Animal Nutrition, Department of Animal Science, \\ Biotechnical Faculty, University of Ljubljana \\ Groblje 3, 1230 Domzale, Slovenia
}

(Received 10 September 2004; revised version 30 December 2004; accepted 18 March 2005)

\begin{abstract}
To evaluate the possible interaction between tannins and the activity of exogenous feed enzymes, the effect of tannin supplementation on added phytase efficiency in pigs was studied. An extract of sweet chestnut (Castanea sativa Mill.) wood was used as the source of tannins. Thirty-six pigs were divided into five groups: control (no supplement), Phy (550 PU/kg, 0 g tannins), Phy+T1 (550 PU/kg, $1.1 \mathrm{~g}$ tannins/ $\mathrm{kg}$ ), Phy+T2 (550 PU/kg, $2.2 \mathrm{~g}$ tannins $/ \mathrm{kg}$ ) and Phy+T3 (550 PU/kg, $4.5 \mathrm{~g}$ tannins $/ \mathrm{kg}$ ). The results proved that phytase supplementation in the Phy group significantly increased apparent $\mathrm{P}$ digestibility and balance, Ca balance, serum inorganic $\mathrm{P}$ concentration, significantly reduced serum Ca concentration, numerically improved apparent nitrogen digestibility and significantly increased the $\mathrm{N}$ balance. Compared with the Phy group, the addition of tannins significantly reduced apparent protein digestibility. The apparent crude ash digestibility in the Phy+T3 group was also reduced $(\mathrm{P}<0.08)$. The utilization of phosphorus and calcium was unaffected by tannin supplementation. In conclusion, the applied concentrations of tannins did not reduce the phosphorus-related efficiency of phytase action in growing pigs.
\end{abstract}

KEY WORDS: pigs, tannins, phytase, phosphorus, calcium, protein

\section{INTRODUCTION}

Various exogenous feed enzymes have proved their efficiency in animal nutrition. However, information is lacking about the effect of various feed

\footnotetext{
"Supported by a grant from the Ministry of Agriculture, Food and Forestry and the Ministry of Education, Science and Sports of the Republic of Slovenia

${ }^{1}$ Corresponding author: e-mail: janez.salobir@bfro.uni-lj.si
} 
constituents and supplements on the activity of exogenous enzymes in the digestive tract.

In animal nutrition, tannins are usually regarded as antinutritive substances, but in appropriate concentrations they can also exhibit beneficial effects that are based on their antimicrobial, anthelminthic, and antioxidative properties. Tannins in various plant extracts act to prevent or dissociate the colonization of intestinal parasites, bacteria, protozoa, and viruses and are widely used in traditional medicine to counter diarrhoea and dysentery (Lewis, 2003). Several authors have reported reduced incidence of diarrhoea and mortality in farm animals as consequences of the use of tannins from various plant extracts as feed supplements (Essl and Huber, 1998; Ishihara et al., 2001).

Tannins form complexes with proteins, thereby reducing protein and amino acid digestibility. This negative effect also occurs due to binding to, and consequent inhibition of, endogenous enzymes (Jansman, 1993). In this context the question whether tannins also influence the activity of exogenous enzymes seems to be important as well.

The aim of the present study was to evaluate the effect of different tannin concentrations on the efficiency of exogenous phytase action by measuring mineral and protein utilization and some relevant blood parameters in pigs. The source of tannins was a wood extract of hydrolysable and mainly condensed form of sweet chestnut tannins (Castanea sativa Mill.).

\section{MATERIAL AND METHODS}

Thirty-six castrated male fattening pigs ( $65 \mathrm{~kg}$ liveweight) were penned singly in metabolism cages that allowed separate collection of faeces and urine. The adaptation and total excreta collection period lasted 10 and 7 days, respectively. At the end of the experiment blood samples were drawn for serum mineral analysis.

The animals were fed 2.5 times the maintenance requirement and received daily $2005 \mathrm{~g}$ of a barley-maize-soyabean meal-based diet without inorganic phosphorus supplementation. The feed was composed of, \%: maize 35 , barley 50.1 , soyabean meal 12.3 , salt 0.3 , limestone 1.6 , lysine 0.2 , and vitamin-mineral premix 0.5 . According to chemical analysis the feed contained, $\mathrm{g} / \mathrm{kg}$ : dry matter 898 , crude protein 144, crude ash 43.7, Ca 7.3, and total P 3.7. The feed was calculated to contain 11.9 MJ metabolizable energy and $1.1 \mathrm{~g}$ digestible $\mathrm{P}$ per $\mathrm{kg}$.

At the beginning of the experiment the animals were randomly assigned to five groups. All of the groups received the same diet, which was supplemented or unsupplemented with phytase and tannins. Phytase (measured in phytaseunits, PU) was provided as the Natuphos preparation (BASF, Germany). Tannins were provided as sweet chestnut tannin (Castanea sativa Mill.), a wood extract 
preparation containing 55\% tannins (Farmatan, Tanin-Sevnica, Slovenia). The following dietary treatments were provided: (Table 1$)$ : negative control group $(0$ $\mathrm{PU} / \mathrm{kg}, 0 \mathrm{~g}$ tannins), positive control group Phy (550 PU/kg, $0 \mathrm{~g}$ tannins), and three groups supplemented with phytase and different tannin concentrations: Phy+T1 (550 PU/kg, $1.1 \mathrm{~g}$ tannins $/ \mathrm{kg}$ ), Phy+T2 (550 PU/kg, $2.2 \mathrm{~g}$ tannins $/ \mathrm{kg}$ ) and Phy+T3 (550 PU/kg, $4.5 \mathrm{~g}$ tannins $/ \mathrm{kg}$ ).

TABLE 1

Dietary treatments and analysed total tannin content of the diets

\begin{tabular}{lccccc}
\hline \multicolumn{1}{c}{ Indices } & Control & Phy & Phy+T1 & Phy+T2 & Phy+T3 \\
\hline No of animals & 7 & 8 & 7 & 7 & 7 \\
Chestnut tannins', $\mathrm{g} / \mathrm{kg}$ & 0 & 0 & 1.1 & 2.2 & 4.5 \\
Total tannins content, g/kg & 0.63 & 0.63 & 1.57 & 2.61 & 5.33 \\
Phytase $^{2}, \mathrm{U} / \mathrm{kg}$ & 0 & 550 & 550 & 550 & 550 \\
\hline
\end{tabular}

${ }^{1}$ provided as a sweet chestnut tannin extract preparation containing $55 \%$ tannins (Farmatan, Tanin-Sevnica, Slovenia)

${ }^{2}$ calculated content; Natuphos (BASF, Germany)

During collection urine was pre-acidified to a pH lower than 3.0 using $18 \%$ $\mathrm{HCl}$. Faeces and urine were quantitatively collected twice daily and stored at $-20^{\circ} \mathrm{C}$. The contents of crude nutrients, phosphorus, and tannin in diets and excreta were determined by standard procedures (Naumann and Bassler, 1999).

The data were analysed by the General Linear Models (GLM) procedure from $\mathrm{SAS}^{\circledR}$ software (2000). Comparisons between treatments were made by contrasts provided by the GLM procedure. The data are expressed as least square means \pm pooled standard error of mean (SEM).

\section{RESULTS AND DISCUSSION}

The animals adapted well to the experimental conditions and had no health or other problems, consumed feed without refusals, and normal body weight gain ( $533 \pm 66$ g per day) for this level of feeding was observed.

In order to measure the effect of tannins on phytase efficiency, the positive effect of phytase on mineral and nitrogen utilization had to be confirmed. Indeed, comparison of the control and Phy groups proved that phytase supplementation significantly improved nitrogen, calcium and phosphorus utilization. In the case of nitrogen utilization (Table 2), this was shown by the significantly reduced nitrogen excretion with faeces, somewhat improved apparent nitrogen digestibility, and significantly increased $\mathrm{N}$ balance. The comparison also showed that adding phytase significantly reduced faecal $\mathrm{P}$ excretion, increased $\mathrm{P}$ digestibility, reduced urinary $\mathrm{Ca}$ excretion, increased 
$\mathrm{P}$ and $\mathrm{Ca}$ balance, and improved $\mathrm{P}$ and $\mathrm{Ca}$ utilization (Table 3). Phytase supplementation also significantly increased serum $\mathrm{P}$ and tended $(\mathrm{P}<0.06)$ to decrease the serum $\mathrm{Ca}$ concentration. These results were expected and are similar to those of other studies, which also reported improved phosphorus and

TABLE 2

The influence of chestnut tannins and phytase on nitrogen utilization

\begin{tabular}{lcccccc}
\hline \multicolumn{1}{c}{ Indices } & Control & Phy & Phy+T1 & Phy+T2 & Phy+T3 & SEM \\
\hline Nitrogen & & & & & & \\
intake, g/day & 46.2 & 46.2 & 46.2 & 46.2 & 46.2 & \pm 0.0 \\
faeces, g/day & $8.7^{\mathrm{a}}$ & $7.6^{\mathrm{h}}$ & $9.0^{\mathrm{at}}$ & $9.5^{\mathrm{ac}}$ & $10.1^{\mathrm{c}}$ & \pm 0.7 \\
urine, g/day & 22.2 & 20.9 & 20.9 & 20.9 & 20.5 & \pm 1.8 \\
apparent digestibility, \% & $81.2^{\text {ah }}$ & $83.6^{\mathrm{b}}$ & $80.6^{\mathrm{ab}}$ & $79.4^{\mathrm{h}}$ & $78.1^{\mathrm{a}}$ & \pm 0.9 \\
balance', g/day & $15.2^{\mathrm{u}}$ & $17.7^{\mathrm{h}}$ & $16.2^{\mathrm{bb}}$ & $15.7^{\mathrm{ab}}$ & $15.5^{\mathrm{a}}$ & \pm 0.2 \\
\hline
\end{tabular}

a.h means without the same superscripts in the same line differ significantly; $\mathrm{P} \leq 0.05$

'Phy vs Phy+T3 $(\mathrm{P}<0.10)$

TABLE 3

The influence of chestnut tannins and phytase on some minerals utilization and on serum mineral and alkaline phosphatase concentrations

\begin{tabular}{|c|c|c|c|c|c|c|}
\hline Indices & Control & Phy & Phy+-T1 & Phy+T2 & Phy+T3 & SEM \\
\hline \multicolumn{7}{|l|}{ Crude ash } \\
\hline intake, $\mathrm{g} /$ day & 87.7 & 87.7 & 87.7 & 87.7 & 87.7 & \pm 0.0 \\
\hline faeces, $g /$ day & 53.4 & 43.2 & 47.9 & 47.2 & 50.0 & \pm 2.9 \\
\hline apparent digestibility', \% & $39.0^{4}$ & $50.8^{b}$ & $45.4^{\text {th }}$ & $46.1^{\text {ath }}$ & $43.0^{\mathrm{a}}$ & \pm 3.4 \\
\hline \multicolumn{7}{|l|}{ Phosphorus } \\
\hline intake, $g /$ day & 7.54 & 7.54 & 7.54 & 7.54 & 7.54 & \pm 0.00 \\
\hline faeces, g/day & $5.36^{\mathrm{i}}$ & $4.69^{b}$ & $4.64^{b}$ & $4.62^{b}$ & $4.92^{\text {sh }}$ & \pm 0.17 \\
\hline urine, $\mathrm{g} /$ day & 0.093 & 0.081 & 0.108 & 0.061 & 0.204 & \pm 0.073 \\
\hline apparent digestibility, $\%$ & $28.8^{3}$ & $37.8^{b}$ & $38.4^{\mathrm{b}}$ & $38.6^{\mathrm{b}}$ & $34.8^{\text {ab }}$ & \pm 2.32 \\
\hline balance, $\mathrm{g} /$ day & $2.08^{\mathrm{a}}$ & $2.77^{\mathrm{b}}$ & $2.79^{\mathrm{b}}$ & $2.86^{\mathrm{b}}$ & $2.42^{\mathrm{ab}}$ & \pm 0.19 \\
\hline \multicolumn{7}{|l|}{ Calcium } \\
\hline intake, $\mathrm{g} /$ day & 14.57 & 14.57 & 14.57 & 14.57 & 14.57 & \pm 0.00 \\
\hline faeces, $g /$ day & 10.85 & $10.3 !$ & 9.99 & 10.49 & 10.93 & \pm 0.43 \\
\hline urine, $g /$ day & $2.49^{: 1}$ & $1.14^{\mathrm{h}}$ & $1.18^{\mathrm{b}}$ & $0.91^{\mathrm{h}}$ & $1.06^{\mathrm{h}}$ & \pm 0.14 \\
\hline apparent digestibility, $\%$ & 25.7 & 29.4 & 31.3 & 28.2 & 24.8 & \pm 3.0 \\
\hline balance, g/day & $1.22^{\mathrm{a}}$ & $3.11^{\mathrm{b}}$ & $3.40^{\mathrm{k}}$ & $3.16^{\mathrm{h}}$ & $2.58^{\mathrm{ab}}$ & \pm 0.47 \\
\hline \multicolumn{7}{|l|}{ Serum } \\
\hline inorganic $\mathrm{P}, \mathrm{mmol} / \mathrm{L}$ & $2.12^{a}$ & $2.33^{\mathrm{b}}$ & $2.42^{b}$ & $2.32^{\mathrm{b}}$ & $2.27^{\mathrm{ab}}$ & \pm 0.05 \\
\hline $\mathrm{Ca}^{2}, \mathrm{mmol} / \mathrm{L}$ & 2.84 & 2.71 & 2.81 & 2.83 & 2.78 & \pm 0.05 \\
\hline
\end{tabular}

a.t means without the same superscripts in the same line differ significantly; $\mathrm{P} \leq 0.05$

' control vs Phy $(\mathrm{P}=0.08)$ and Phy vs $\mathrm{Phy}+\mathrm{T} 3(\mathrm{P}=0.08)$

2 control vs Phy $(\mathrm{P}<0.06)$, Phy vs $\mathrm{Phy}+\mathrm{T} 1(\mathrm{P}<0.07)$, Phy vs Phy+T2 $(\mathrm{P}<0.10)$ 
calcium utilization after phytase supplementation (Yi et al., 1996). The increased calcium retention was probably not the consequence of an improved calcium supply but of an improved phosphorus availability, which was also indicated by the results of blood serum analysis. High urinary calcium excretion, decreased phosphorus and increased calcium blood levels are indicators of phosphorus deficiency and of a high level of phosphorus mobilization from the bones (Rose, 1994).

Comparison of the tannin-supplemented groups with the Phy group showed that sweet chestnut tannin extract, like tannic acid and the tannins from various beans and sorghum (Jansman, 1993), also increase faecal protein excretion and reduce protein digestibility. The effect of tannins was related to their concentration: the strongest effect was observed in the group receiving the highest concentration of tannins, in which significantly lower digestibility and utilization of proteins were noticed. The observed nitrogen excretion in the Phy $+\mathrm{T} 3$ group was even higher than in the control group. The results indicate that tannins reduce protein digestibility to an extent that can be higher than the improvement achieved by phytase.

In contrast to apparent crude protein utilization, supplementation at all three tannin concentrations did not prove to have a significant effect on crude ash, P and $\mathrm{Ca}$ utilization or on the concentration of minerals in the blood. So the improvement of mineral utilization achieved by exogenous phytase was not significantly affected. But it cannot be overlooked that in the group with the highest tannin supplementation (Phy+T3) the phosphorus excretion rate in faeces, apparent digestibility and balance, calcium balance and serum inorganic phosphate level were not significantly different from the values in the control group. This observation indicates that tannin supplementation at this level $(4.5 \mathrm{~g} / \mathrm{kg})$ might already affect phytase activity and, consequently, phosphorus utilization.

The results of this study proved that tannin supplementation at the applied levels reduced protein but not phosphorus utilization of feed with added phytase. Since tannins supplemented at rates up to at least $2.2 \mathrm{~g} / \mathrm{kg}$ feed had no effect on exogenous phytase, they might also have no effect on exogenous proteinases in the phytase preparation. It might be speculated that tannin supplementation, at least to a certain level, affects only the endogenous digestive enzymes and has no effect on exogenous enzymes.

\section{CONCLUSIONS}

On the basis of this study it can be concluded that, under the experimental conditions applied, the sweet chestnut tannin extract did not significantly reduce the phosphorus-related efficiency of phytase action in growing pigs. In contrast, the positive effect of phytase on protein digestibility was significantly reduced. The question whether reduced protein digestibility was due to reduced 
activity of proteinases in the phytase preparation or of endogenous enzymes remains unanswered. Because of the variable response of different proteins to various tannins the question whether other forms of tannins (for instance those encountered in various feedstuffs) have any particular influence on phytase and other exogenous enzymes remains to be answered.

\section{REFERENCES}

ALVA (Arbeitsgemeinschaft Landwirtschaftlicher Versuchsanstalten in Österreich), 1983. Öesterreichisches Methodenbuch für die Untersuchung von Futtermitteln, Futterzusatzstoffen und Schadstoffen. 7.08. Bestimmung von Calcium. ALVA. Wien

Essl A., Huber H., 1998. Use of Farmatan in weaned pigs. Krmiva 40, 299-300

Ishihara N., Chu D.C., Akachi S., Juneja L.R., 2001. Improvement of intestinal microflora balance and prevention of digestive and respiratory organ diseases in calves by green tea extracts. Livest. Prod. Sci. 68, 217-229

Jansman A.J.M., 1993. Tannins in feedstuffs for simple-stomached animals. Nutr. Res. Rev. 6, 209236

Lewis W.H., 2003. Medical Botany: Plants Affecting Human Health. $2^{\text {nd }}$ Edition. John Wiley and Sons, Hoboken, pp. 459-485

Naumann C., Bassler R. (Editors), 1999. Methodenbuch. Band III. Die chemische Untersuchung von Futtermitteln. Band III. VDLUFA-Verlag, Darmstadt

Rose B.D., 1994. Clinical Physiology of Acid-Base and Electrolyte Disorders. $4^{\text {th }}$ Edition. McGrawHill, New York, pp. 150-215

SAS, 2000. Statistical Analysis Systems Institute. SAS/STAT User's Guide: Statistics, Release 8e. SAS Institute Inc., Cary, NC

Yi Z., Kornegay E.T., Ravindran V., Lindemann M.D., Wilson J.H., 1996. Effectiveness of Natuphos $\mathrm{R}$ phytase in improving the bioavailabilities of phosphorus and other nutrients in soybean mealbased semipurified diets for young pigs. J. Anim. Sci. 74, 1601-1611

\section{STRESZCZENIE}

Dodatek tanin do dawek pokarmowych zawierających fitazę obniża wykorzystanie białka, ale nie fosforu przez świnie

Celem oceny czy istnieją interakcje między działaniem tanin a egzogennymi enzymami paszy, badano wpływ dodatku tanin na efektywność dodanej fitazy do diet dla świń. Źródło tanin stanowił ekstrakt z drzewa słodkiego kasztanowca (Castanea sativa Mill.). Trzydzieści sześć świń podzielono na 5 grup: kontrolną (bez dodatku), Phy (550 PU/kg, 0 g tanin), Phy+T1 (550 PU/kg; $1,1 \mathrm{~g}$ tanin $/ \mathrm{kg}$ ), Phy+T2 (550 PU/kg; $2,2 \mathrm{~g} \operatorname{tanin} / \mathrm{kg}$ ) i Phy+T3 (550 PU/kg; 4,5 g tanin $/ \mathrm{kg})$.

Dodatek fitazy w grupie Phy istotnie zwiększył pozorną strawność i bilans P, bilans Ca oraz stężenie nieorganicznego P w surowicy krwi, a istotnie obniżył stężenie Ca w surowicy, liczbowo nieistotnie pozorną strawność azotu, a istotnie bilans N. Dodatek tanin istotnie obniżył pozorną strawność azotu w porównaniu z grupą Phy. Pozorna strawność popiołu była także mniejsza w grupie Phy+T3. Dodatek tanin nie wpłynął na wykorzystanie $\mathrm{P}$ i Ca.

W podsumowaniu stwierdzono, że zastosowany dodatek tanin nie obniżył efektywności działania fitazy u rosnących świń. 